\title{
Ethynylthioamide Complexes: Synthesis, Reactivity and an Unusual Coupling Reaction with Diethylaminopropyne
}

\author{
Normen Szesni, Matthias Drexler, Bernhard Weibert, and Helmut Fischer \\ Fachbereich Chemie, Universität Konstanz, Fach M727, D-78457 Konstanz, Germany \\ Reprint requests to Prof. Dr. H. Fischer. E-mail: helmut.fischer@uni-konstanz.de
}

Z. Naturforsch. 2007, 62b, 346-356; received July 20, 2006

Dedicated to Prof. Helgard G. Raubenheimer on the occasion of his $65^{\text {th }}$ birthday

The reaction of $\left[(\mathrm{CO})_{5} \mathrm{Cr}(\mathrm{THF})\right]$ with propynethioic acid amides, $\mathrm{R}-\mathrm{C} \equiv \mathrm{C}-\mathrm{C}(=\mathrm{S}) \mathrm{NMe}_{2}(\mathrm{R}=\mathrm{H}$, $\left.\mathrm{SiMe}_{3}\right)$, yields the thioamide complexes $\left[(\mathrm{CO})_{5} \mathrm{Cr}-\mathrm{S}=\mathrm{C}\left(\mathrm{NMe}_{2}\right) \mathrm{C} \equiv \mathrm{C}-\mathrm{H}\right](\mathbf{1 a})$ and $\left[(\mathrm{CO})_{5} \mathrm{Cr}-\right.$ $\left.\mathrm{S}=\mathrm{C}\left(\mathrm{NMe}_{2}\right) \mathrm{C} \equiv \mathrm{C}-\mathrm{SiMe}_{3}\right](\mathbf{1 b})$. Treatment of solutions of $\mathbf{1 a}$ or $\mathbf{1 b}$ with methyllithium generates, via deprotonation or desilylation, the lithium salt $\mathrm{Li}\left[(\mathrm{CO})_{5} \mathrm{Cr}-\mathrm{S}=\mathrm{C}\left(\mathrm{NMe}_{2}\right) \mathrm{C} \equiv \mathrm{C}\right](2)$. On filtration over silica, $\mathbf{2}$ is readily reprotonated. Complex $\mathbf{1 a}$ is inert towards methanol, however, adds diethylamine across the $\mathrm{C} \equiv \mathrm{C}$ bond to give the thioacrylamide complex $\left[(\mathrm{CO})_{5} \mathrm{Cr}-\mathrm{S}=\mathrm{C}\left(\mathrm{NMe}_{2}\right) \mathrm{C}(\mathrm{H})=\mathrm{C}(\mathrm{H}) \mathrm{NMe}_{2}\right]$ (3). Thiourea displaces the thioamide ligand to give $\left[(\mathrm{CO})_{5} \mathrm{Cr}-\mathrm{S}=\mathrm{C}\left(\mathrm{NH}_{2}\right)_{2}\right](4)$. Complex 1a reacts with half an equivalent of diethylaminopropyne in a three-component coupling to form the homobinuclear complex $\left[(\mathrm{CO})_{5} \mathrm{Cr}-\mathrm{S}=\mathrm{C}\left(\mathrm{NEt}_{2}\right)-\mathrm{C}\left(\mathrm{CH}_{3}\right)=\mathrm{C}(\mathrm{H})-\mathrm{C}(\mathrm{H})=\mathrm{C}\left(\mathrm{NMe}_{2}\right)-\mathrm{C} \equiv \mathrm{C}-\mathrm{C}\left(\mathrm{NMe}_{2}\right)=\mathrm{S}-\right.$ $\left.\mathrm{Cr}(\mathrm{CO})_{5}\right](\mathbf{5})$ in high yield. The solid state structures of complexes $\mathbf{1 a}$ and $\mathbf{5}$ were established by $\mathrm{X}$-ray structural analyses. Key words: Thioamide Complexes, Chromium Complexes, Nucleophilic Addition, Coupling
Reaction

\section{Introduction}

Thioamides exhibit versatile coordination properties and have been used as ligands in a variety of transition metal complexes. In complexes, thioamides can act as $N$-, $S$-, or $N, S$-donating groups in a terminal or a bridging mode and are capable of generating mononuclear, polynuclear or polymeric complexes [1]. $\alpha, \beta$ Unsaturated thioamides (thioacrylamides) carry an additional functional group for potential coordination to transition metals in addition to nitrogen and sulphur. Although a number of complexes have been prepared and structurally characterized the reactivity of coordinated thioacrylamides has only been explored to a minor degree [2]. Non-coordinated thioacrylamides were found to be excellent Michael acceptors. They readily add nucleophiles like organolithium and -magnesium compounds, enolates of ketones, esters and amides or amines across the $\mathrm{C}=\mathrm{C}$ bond. The scope of the reactivity could be extended to considerably less reactive nucleophiles like sodium malonates by coordination of thioacrylamides to palladium [3]. Via coordination to a tricarbonyliron fragment acrylthioamides could be induced to form carbocyclization products in good yields in the reaction with alkynes and carbon monoxide [4].

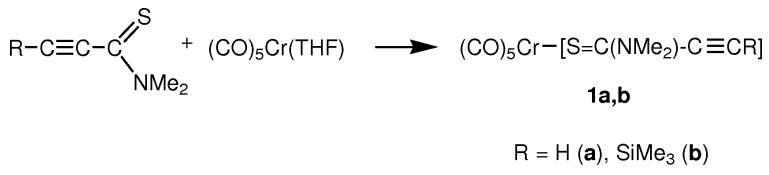

Scheme 1.

Thioamide complexes containing an $\alpha, \beta$ carboncarbon triple bond are unknown until now. In this account we report on the synthesis of the first thioamide complexes derived from propynoic acid, on the coordination mode of these unsaturated thioamide ligands and on the results of some preliminary studies on the reactivity towards simple nucleophiles as well as towards diethylaminopropyne as an example for electron-rich alkynes.

\section{Results and Discussion}

The complex $\left[(\mathrm{CO})_{5} \mathrm{Cr}(\mathrm{THF})\right]$ reacts readily with propynethioic acid amides by displacement of the weakly coordinating THF ligand to form the propynethioic acid amide complexes $\mathbf{1 a}$ and $\mathbf{1 b}$ (Scheme 1). At ambient temperature the reaction is complete within minutes affording, after chromatography, $\mathbf{1 a}$ and $\mathbf{1 b}$ in $96 \%$ and $93 \%$ yield, respectively. By the same method 


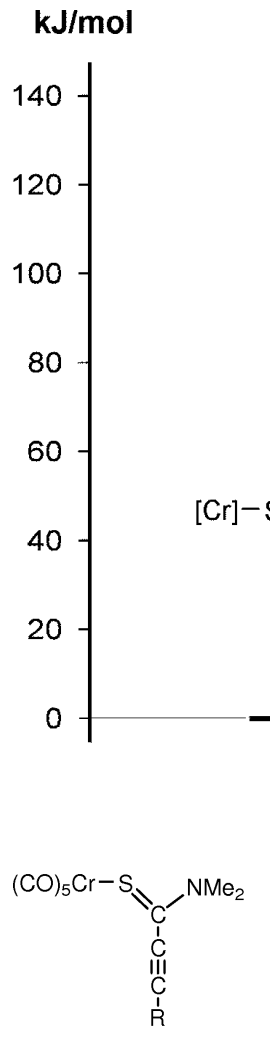

(A)

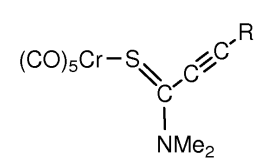

(B)

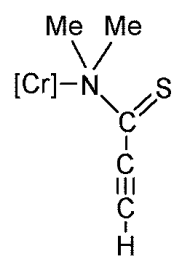

A $\quad$ B

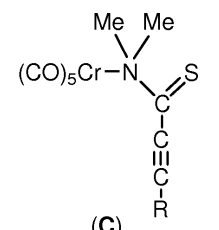

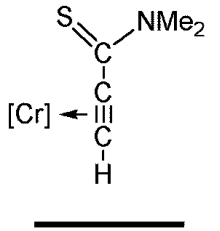

Fig. 1. Relative energies of the various isomers of complex 1a as calculated on the LACVP*/BP86 level of theory.

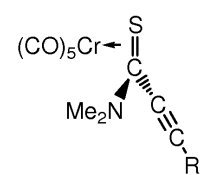

(D)<smiles>[R]C=C(C(=O)OC(C)(C)C)C(=S)N(C)C</smiles>

(E)
Scheme 2 .

pentacarbonyl thiourea and thiocarbonato complexes of chromium, molybdenum, and tungsten have previously been synthesized [5].

The new complexes $\mathbf{1 a}$ and $\mathbf{1 b}$ are stable in an inert gas atmosphere and are soluble in common organic solvents. These complexes were fully characterized by spectroscopic means and elemental analysis. The IR spectra of $\mathbf{1 a}$ and $\mathbf{1 b}$ show the typical pattern of a pseudo-octahedral $\left[(\mathrm{CO})_{5} \mathrm{M}-\mathrm{L}\right]$ complex. Several isomers for $\mathbf{1 a}, \mathbf{b}$ are conceivable $(\mathbf{A}-\mathbf{E}$, Scheme 2$)$ due to the multifunctionality of the propynethioic acid amide ligand.

The coordination mode of thioketones and thioaldehydes to transition metals strongly depends on the substitution pattern and the co-ligand sphere. In pentacarbonyl transition metal complexes thioketones and thioaldehydes usually coordinate via one of the two lone electron pairs at the sulphur atom $\left(\eta^{1}\right.$ coordination modes $\mathbf{A}$ and $\mathbf{B}$ ) [6]. An equilibrium between $\eta^{1}$ and $\eta^{2}$ isomers in solution (corresponding to isomers $\mathbf{A} / \mathbf{B}$ and $\mathbf{D}$ ) was observed for some thiobenzaldehyde complexes of tungsten [7] and of ruthenium [8]. The isomers were found to rapidly interconvert. Exclusively the $\eta^{2}$ coordination mode, comparable to $\mathbf{D}$, was found in thioaldehyde complexes of titanium, zirconium, tantalum, iron, rhenium, rhodium, osmium, and some cyclopentadienyl molybdenum complexes [6]. Some thioketone ligands in vanadium, cobalt, rhodium, palladium, and platinum complexes also exhibit $\eta^{2}$ coordination [6]. The rapid interconversion of two $\eta^{1}$ thioaldehyde isomers (corresponding to an interconversion of $\mathbf{A}$ and $\mathbf{B}$ ) was also observed [9].

In addition to $\eta^{1}(\mathrm{~S})$ and $\eta^{2}(\mathrm{C}=\mathrm{S})$ coordination, bonding via the lone electron pair at the nitrogen atom (C) and via the CC triple bond (E) is likewise conceivable.

The position of the $v(\mathrm{CO})$ absorptions at rather low energy indicates that the thioamide ligand is a strong donor. In the ${ }^{1} \mathrm{H}$ and the ${ }^{13} \mathrm{C}$ NMR spectra, complexes $\mathbf{1 a}$ and $\mathbf{1 b}$ show two sets of methyl resonances, however, only one set of signals for the remaining hydrogen and carbon atoms. Therefore, the coordination modes 


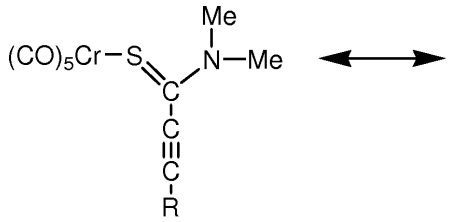

(F)

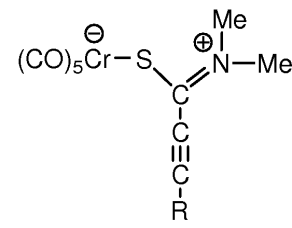

(G)
Scheme 3 .

$\mathbf{C}-\mathbf{E}$ can be excluded. In $\mathbf{C}$ both methyl groups are equivalent and should give rise to only one methyl resonance. In the $\eta^{2}$ bonding modes $\mathbf{D}$ and $\mathbf{E}$ the thioamide ligand is expected to exhibit pronounced $\pi$ acceptor properties and the $v(\mathrm{CO})$ absorptions should appear at considerably higher energy. The observation of only one set of ${ }^{13} \mathrm{C}$ resonances for the $\mathrm{C}_{3}$ fragment indicates the presence of only structures $\mathbf{A}$ or $\mathbf{B}$, or of a rapidly interconverting equilibrium of $\mathbf{A}$ and $\mathbf{B}$ in solution. In the solid state (see below) $\mathbf{1 a}$ adopts conformation $\mathbf{A}$ ( $E$ isomer with respect to the $\mathrm{C}=\mathrm{S}$ bond). Very likely, the same isomer is present in solution. An $\eta^{1}$ coordination mode comparable to $\mathbf{A}$ has also been reported for related thioacrylamide complexes [2a, $2 b$, 10]. The assumption is in accord with the results of DFT calculations on 1a. Isomer $\mathbf{B}$ was calculated to be $29 \mathrm{~kJ} / \mathrm{mol}$ higher in energy than isomer $\mathbf{A}$. Isomer $\mathbf{E}$ is higher in energy than $\mathbf{B}$ only by about $5 \mathrm{~kJ} / \mathrm{mol}$ (34 kJ/mol with respect to A) whereas the "amine" isomer $\mathbf{C}$ is considerably higher in energy (by $99 \mathrm{~kJ} / \mathrm{mol}$ ) (Fig. 1). For isomer D no local minimum on the energy surface could be located.

The inequivalence of the methyl resonances in the NMR spectra indicates hindered rotation around the $\mathrm{C}-\mathrm{NMe}$ bond and some double-bond character of this bond. From the temperature-dependence of the ${ }^{1} \mathrm{H}$ NMR spectra in $\mathrm{C}_{6} \mathrm{D}_{5} \mathrm{CD}_{3}$ the energy barrier to rotation around the $\mathrm{C}-\mathrm{NMe}$ bond in $\mathbf{1 b}$ is calculated to be $\Delta G^{\#}=79.6 \mathrm{~kJ} / \mathrm{mol}$ (coalescence at $92{ }^{\circ} \mathrm{C}$; compound 1a rapidly decomposed under similar conditions). This emphasizes that the zwitterionic resonance form $\mathbf{G}$ (Scheme 3 ) significantly contributes to the stabilization of the complexes [11].

The structure of complex 1a was additionally confirmed by an X-ray structural analysis (Fig. 2, Table 1). As deduced from the spectroscopic data the thioamide ligand is $\eta^{1}$-bound to the chromium atom and is staggered with respect to the cis- $\mathrm{CO}$ ligands $\left[\mathrm{C}(2)-\mathrm{Cr}(1)-\mathrm{S}(1)-\mathrm{C}(8)=43.98(2)^{\circ}\right]$. The $\mathrm{Cr}(1)-\mathrm{S}(1)$ bond length $(2.417(2) \AA)$ agrees well with that in known thioamide chromium complexes $\left[(\mathrm{CO})_{5} \mathrm{Cr}-\right.$
Table 1. Crystal data and refinement details for the complexes $1 \mathbf{a}$ and 5.

\begin{tabular}{lll}
\hline & $\mathbf{1 a}$ & $\mathbf{5}$ \\
\hline Formula & $\mathrm{C}_{10} \mathrm{H}_{7} \mathrm{CrNO}_{5} \mathrm{~S}$ & $\mathrm{C}_{27} \mathrm{H}_{27} \mathrm{Cr}_{2} \mathrm{~N}_{3} \mathrm{O}_{10} \mathrm{~S}_{2}$ \\
$M_{\mathrm{r}}$ & 305.23 & 721.64 \\
Crystal system & monoclinic & monoclinic \\
Space group & $P 2_{1} / n$ & $P 2_{1} / n$ \\
$a[\AA]$ & $8.6484(13)$ & $10.240(2)$ \\
$b[\AA]$ & $8.237(5)$ & $28.907(6)$ \\
$c[\AA]$ & $9.095(6)$ & $11.683(2)$ \\
$\beta[\mathrm{deg}]$ & $93.68(7)$ & $110.12(3)$ \\
$V\left[\AA^{3}\right]$ & $646.6(6)$ & $3247.2(11)$ \\
$Z$ & 2 & 4 \\
Crystal size $\left[\mathrm{mm}^{3}\right]$ & $0.5 \times 0.4 \times 0.3$ & $0.5 \times 0.5 \times 0.5$ \\
$\rho_{\text {calc }}\left[\mathrm{g} \mathrm{cm}^{-3}\right]$ & 1.568 & 1.476 \\
$\mu,\left[\mathrm{mm}{ }^{-1}\right.$ & 1.056 & 0.854 \\
$F(000)$ & 308 & 1480 \\
$T[\mathrm{~K}]$ & $188(2)$ & $188(2)$ \\
$2 \theta$ range $\left({ }^{\circ}\right)$ & $4.48-53.98$ & $4.46-54.18$ \\
Index range & $-10 \leq h \leq 11$ & $-12 \leq h \leq 13$ \\
& $-10 \leq k \leq 10$ & $-36 \leq k \leq 0$ \\
Number of data & $-11 \leq l \leq 11$ & $-14 \leq l \leq 0$ \\
Number of unique data & 2240 & 7417 \\
Parameters & 1521 & 7076 \\
$R(F)$ for $I \geq 2 \sigma(I)$ & 99 & 397 \\
$w R_{2}\left(F^{2}\right)$ for all data & 0.0490 & 0.0492 \\
Goodness-of-fit on $F^{2}$ & 0.1107 & 0.1185 \\
\hline & 1.061 & 1.047 \\
\hline
\end{tabular}

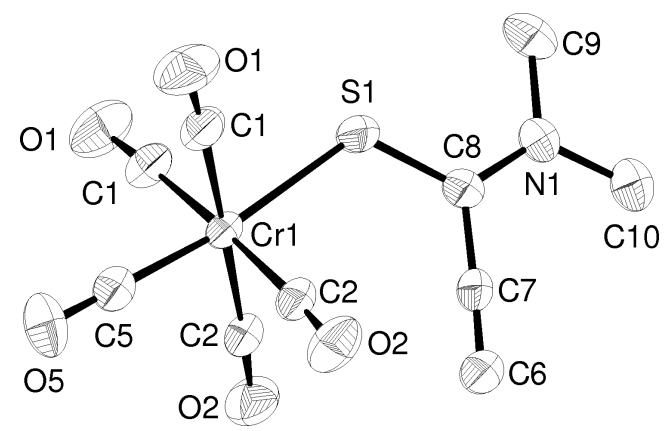

Fig. 2. Plot of the molecular structure of complex 1a (ellipsoids drawn at $50 \%$ level, hydrogen atoms omitted). Selected bond lengths $(\AA)$ and angles $\left({ }^{\circ}\right)$ are: $\operatorname{Cr}(1)-\mathrm{C}(1)$ 1.893(3), $\mathrm{Cr}(1)-\mathrm{C}(2)$ 1.883(3), $\mathrm{Cr}(1)-\mathrm{C}(5)$ 1.830(5), $\mathrm{Cr}(1)-$ $\mathrm{S}(1) 2.417(2), \mathrm{S}(1)-\mathrm{C}(8)$ 1.667(4), C(8)-N(1) 1.326(5), $\mathrm{C}(8)-\mathrm{C}(7)$ 1.431(5), $\mathrm{C}(7)-\mathrm{C}(6)$ 1.157(6); $\mathrm{Cr}(1)-\mathrm{S}(1)-$ $\mathrm{C}(8) \quad 118.46(14), \quad \mathrm{S}(1)-\mathrm{C}(8)-\mathrm{N}(1) \quad 121.3(3), \quad \mathrm{S}(1)-\mathrm{C}(8)-$ C7(1) 121.0(3), N(1)-C(8)-C(7) 117.7(4), C(6)-C(7)-C(8) $178.3(4)$

$\left.\mathrm{S}=\mathrm{C}\left(\mathrm{NMe}_{2}\right)-\mathrm{S}-\mathrm{C}(=\mathrm{O}) \mathrm{NMe}_{2}\right](2.449(1) \AA)$ [2a] and [(CO) $\left.)_{5} \mathrm{Cr}-\mathrm{S}=\mathrm{C}\left(\mathrm{NMe}_{2}\right) \mathrm{Me}\right] \quad(2.454(1) \AA) \quad[12]$. The trigonal-planar environment of the atoms $\mathrm{C}(8)$ and $\mathrm{N}(1)$ ( sum of angles $=360^{\circ}$ in both cases) together with the rather short $\mathrm{C}(8)-\mathrm{N}(1)$ distance indicates a partial double bond character of $\mathrm{C}(8)-\mathrm{N}(1)$ comparable to that of aminocarbene complexes [13]. The signifi- 
$\mathrm{Li}^{+}\left\{(\mathrm{CO})_{5} \mathrm{Cr}-\left[\mathrm{S}=\mathrm{C}\left(\mathrm{NMe}_{2}\right)-\mathrm{C} \equiv \mathrm{C}\right]\right\}$

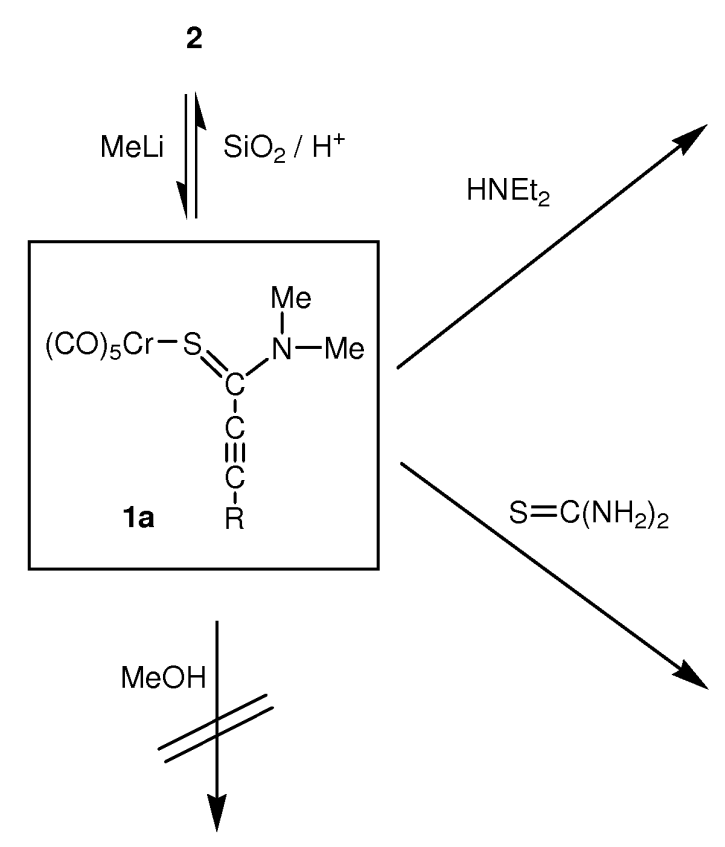<smiles>CCN/C=C/C(=[SH]\C(C)(C)C)N(C)C</smiles><smiles>[R]C#CC(=S)N(C)C</smiles>

Scheme 4.

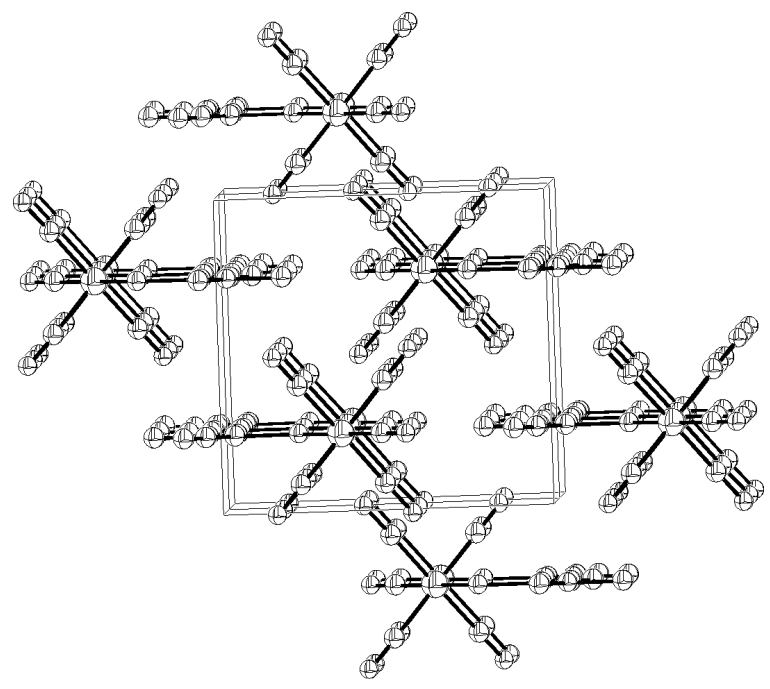

Fig. 3. Molecular stacking of molecules 1a viewed along the $c$ axis of the unit cell.

cant shortening of the $\mathrm{Cr}-\mathrm{CO}_{\text {trans }}$ bond $(1.830(5) \AA)$ when compared to the cis-Cr-CO bonds (average: $1.888 \AA$ ) emphasizes the pronounced trans influence of the thioamide ligand deduced from the IR spectra. In the crystal the molecules of $\mathbf{1 a}$ are arranged in two double-stacks without significant intermolecular inter-

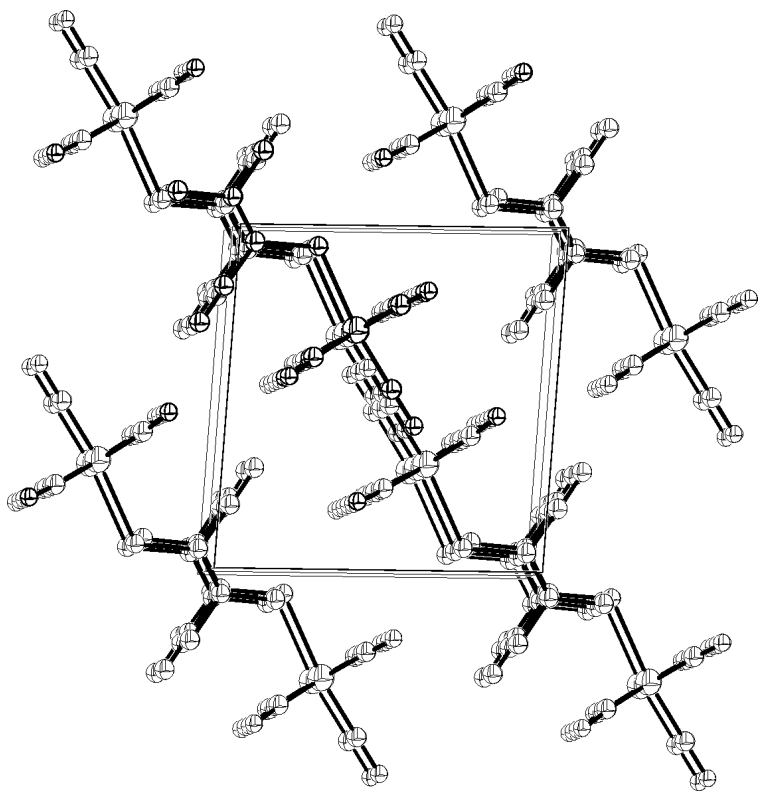

Fig. 4. Molecular stacking of molecules 1a viewed along the $b$ axis of the unit cell.

actions between the stacks: a head-to-tail double-stack along the crystallographic $c$ axis (Fig. 3) and a tail-totail double-stack along the $b$ axis (Fig. 4). 
Complex 1a is readily deprotonated by methyllithium to form the metalate $\mathrm{Li}\left[(\mathrm{CO})_{5} \mathrm{Cr}-\mathrm{S}=\mathrm{C}\left(\mathrm{NMe}_{2}\right)\right.$ $\mathrm{C} \equiv \mathrm{C})$ ] (2) identified by its IR spectrum. The reaction is highly selective. Neither products derived from addition of the carbanion to the triple bond of the thioamide nor a thiolate complex formed by addition of $\left[\mathrm{CH}_{3}\right]^{-}$ to the $s p^{2}$ carbon atom of the $\mathrm{S}=\mathrm{C}$ fragment could be detected. Compound $\mathbf{2}$ is also formed by desilylation of $\mathbf{1 b}$ with methyllithium. On filtration over silica, $\mathbf{2}$ is reprotonated by the protons at the silica surface and 1a is formed in almost quantitative yield (Scheme 4).

Complex 1a is inert towards methanol. In contrast, diethylamine rapidly adds to the triple bond to give the corresponding thioacrylamide 3 in $98 \%$ yield (Scheme 4). From the shift of the trans- $v(\mathrm{CO})$ absorption to longer wavelengths by about $17 \mathrm{~cm}^{-1}$ it follows that the aminothioacrylamide ligand in $\mathbf{3}$ is a considerably better donor than the propynethioic acid amide ligand in 1a. The formation of only one isomer (with respect to the $\mathrm{C}=\mathrm{C}$ bond) could be detected. From the coupling constant of ${ }^{3} \mathrm{~J}=12.1 \mathrm{~Hz}$ for the olefinic hydrogen atoms a cis arrangement can be deduced. Similarly to 1a, two signals are found for the $N$-methyl groups in the NMR spectra of $\mathbf{3}$. The inequivalence of the two N-Et groups shows that the $\mathrm{C}_{\beta}$-bound $\mathrm{NEt}_{2}$ substituent likewise acts as a $\pi$ donor and contributes to the resonance stabilization of the compound. This is in accordance with the shift of the $v(\mathrm{CO})$ absoptions in the IR spectra towards lower energy. In general the spectroscopic data agree well with those of known thioacrylamide complexes [10,14].

Addition of thiourea to solutions of 1a led to displacement of the propynethioic acid amide ligand and to the formation of the thiourea complex $4(95 \%)$ and free thioamide (Scheme 4).

The reaction of 1a with diethylaminopropyne provided an unusual result. Chromium- and tungstencoordinated thioaldehydes and thioketones react with diethylaminopropyne by regioselective $[2+2]$ cycloaddition of the $\mathrm{C} \equiv \mathrm{C}$ bond to the $\mathrm{S}=\mathrm{C}$ bond and subsequent stereoselective electrocylic ring opening to give thioacrylamide complexes [15]. When diethylaminopropyne (DEAP) was added to a solution of $\mathbf{1 a}$ in $\mathrm{CH}_{2} \mathrm{Cl}_{2}$ the starting complex 1a was completely consumed already after the addition of half an equivalent of DEAP. After subsequent chromatography of the reaction mixture the dinuclear complex $\mathbf{5}$ was isolated as the only product in $85 \%$ yield (Scheme 5 ).

In the IR spectrum, complex 5 shows only one set of pentacarbonyl $v(\mathrm{CO})$ absorptions. However, the

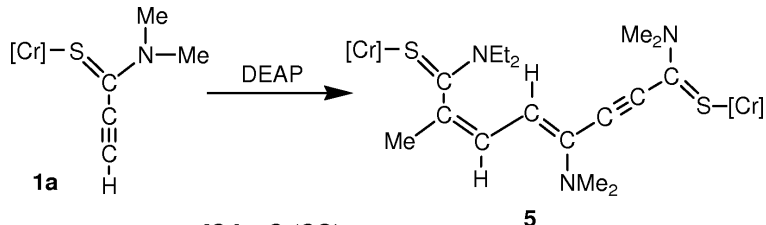

Scheme 5 .

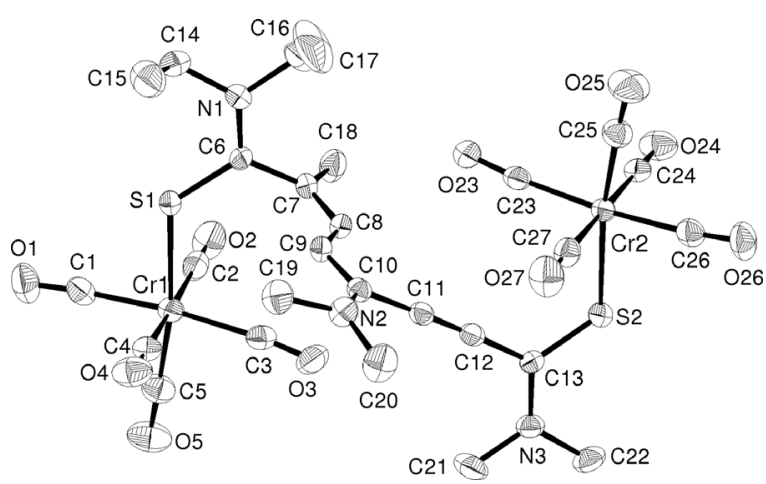

Fig. 5. Plot of the molecular structure of complex $\mathbf{5}$ in the crystal (ellipsoids drawn at $50 \%$ level, hydrogen atoms omitted). Selected bond lengths ( $)$ : $\mathrm{Cr}(1)-\mathrm{C}(1)$ 1.880(4), $\mathrm{Cr}(1)$ $\mathrm{C}(2) 1.909(4), \mathrm{Cr}(1)-\mathrm{C}(3)$ 1.927(4), $\mathrm{Cr}(1)-\mathrm{C}(4)$ 1.892(4), $\mathrm{Cr}(1)-\mathrm{C}(5) \quad 1.849(4), \quad \mathrm{Cr}(1)-\mathrm{S}(1) \quad 2.449(1), \quad \mathrm{Cr}(2)-\mathrm{C}(23)$ 1.908(3), $\mathrm{Cr}(2)-\mathrm{C}(24)$ 1.906(3), $\mathrm{Cr}(2)-\mathrm{C}(25)$ 1.838(3), $\mathrm{Cr}(2)-\mathrm{C}(26)$ 1.892(3), $\mathrm{Cr}(2)-\mathrm{C}(27)$ 1.897(3), $\mathrm{Cr}(2)-\mathrm{S}(2)$ 2.441(1), S(1)-C(6) 1.690(3), C(6)-N(1) 1.324(4), C(6)$\mathrm{C}(7)$ 1.483(4), C(7)-C(8) 1.336(4), C(8)-C(9) 1.432(4), $\mathrm{C}(9)-\mathrm{C}(10)$ 1.364(4), C(10)-C(11) 1.446(4), C(11)-C(12) 1.187(4), C(12)-C(13) 1.432(4), C(13)-S(2) 1.687(3), $\mathrm{C}(13)-\mathrm{N}(3)$ 1.334(4).

${ }^{13} \mathrm{C}$ NMR spectrum exhibits two sets of resonances for cis and trans carbonyl carbon atoms thus indicating the existence of two different pentacarbonylmetal moieties. In addition, two signals are found at rather low field assigned to two inequivalent thiocarbonyl carbon atoms. From the observation of two sets of resonances for the substituents at both amino groups (Me/Me and $\mathrm{Et} / \mathrm{Et}$ ) attached to the thiocarbonyl functionalities again a high barrier to rotation around the (S) $\mathrm{C}-\mathrm{N}$ bonds can be deduced. Unfortunately, the rotational barrier could not be determined due to the rather low thermal stability of $\mathbf{5}$.

The solid state structure of $\mathbf{5}$ was also established by an X-ray structural analysis (Fig. 5, Table 1). Each of the two thioamide groups is $\eta^{1}$-bound to a chromium atom. The $\mathrm{Cr}(1)-\mathrm{S}(1)(2.449(1) \AA)$ and $\mathrm{Cr}(2)-\mathrm{S}(2)$ (2.441(1) $\AA$ ) bond lengths differ slightly and are only marginally longer than in complex 1a. The $\mathrm{N}(1)-\mathrm{C}(6)$ $(1.324(4) \AA)$ and $\mathrm{N}(3)-\mathrm{C}(13)$ bonds $(1.334(4) \AA)$ are 


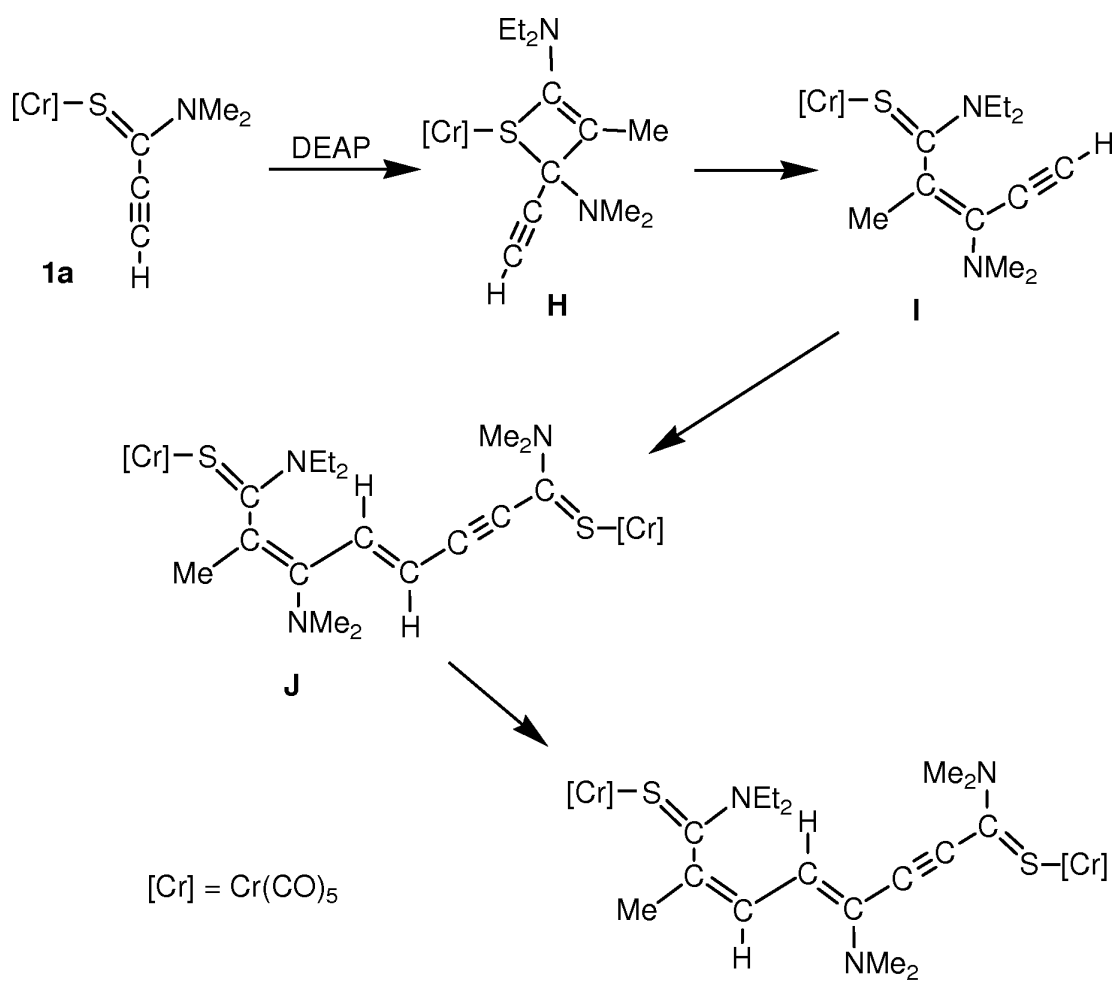

5
Scheme 6. rather short, indicative of partial double bonds. Both thioamide moieties are arranged almost orthogonally to the plane formed by the carbon atoms of the $\pi$ chain $[\mathrm{C}(6)-\mathrm{C}(13)]$ thus excluding electronic communication between the thioamide moieties. The $\mathrm{C}(7)$ $\mathrm{C}(8)$ and $\mathrm{C}(9)-\mathrm{C}(10)$ bonds of the unsaturated carbon array are in good agreement with common $\left[\mathrm{C}\left(s p^{2}\right)\right.$ $\mathrm{C}\left(s p^{2}\right)$ ] double bond lengths, and the $\mathrm{C}(6)-\mathrm{C}(7)$ and $\mathrm{C}(8)-\mathrm{C}(9)$ bonds match with an average $\mathrm{C}\left(s p^{2}\right)-\mathrm{C}\left(s p^{2}\right)$ single bond.

Several mechanisms for the formation of compound 5 are conceivable. The most likely ones are depicted in Schemes 6 and 7. The reaction of 1a with diethylaminopropyne could be initiated by a nucleophilic addition of the $\beta$ carbon atom of the ynamine to the thiocarbonyl carbon atom of $1 \mathbf{a}$ analogously to the reactions of electron-rich alkynes like $\mathrm{Et}_{2} \mathrm{~N}-\mathrm{C} \equiv \mathrm{C}-$ $\mathrm{Me}$ (a) with thioaldehyde complexes to give thioacrylamide complexes or (b) with carbonyl compounds like esters or amides to give acrylamides [16]. Such an initial step could be followed by cyclization and regioselective electrocyclic ring opening $(\mathbf{H} \rightarrow \mathbf{I}$, Scheme 6). Nucleophilic addition of a second molecule of $\mathbf{1 a}$ to the triple bond of I gives J. Subsequent 3,1-H and 1,3-
$\mathrm{NMe}_{2}$ shifts, which presumably contribute to the stabilization of the $\pi$ system, finally afford compound $\mathbf{5}$ (Scheme 6).

An alternative mechanism involves initial 1,4cycloaddition of the $\mathrm{CC}$ triple bond of the ynamine to the $\mathrm{S}=\mathrm{C}-\mathrm{C} \equiv \mathrm{C}$ unit to give $\mathbf{K}$. The 1,4 -cycloaddition of various olefins such as vinyl ethers, styrenes, norbornene, acrolein, and ethyl propiolate to rutheniumcoordinated thiocinnamalaldehydes has recently been reported [17]. Nucleophilic addition of another molecule of 1a and electrocyclic ring opening likewise yield, via $\mathbf{L}$, compound $\mathbf{5}$ (Scheme 7).

The latter mechanism seems more likely, however, neither one of the presumed intermediates of the reaction could be isolated or spectroscopically detected. It is worth mentioning that a similar coupling with a second different alkyne, like for instance 1-hexyne or phenylacetylene, could not be observed, even when the second alkyne was used as the solvent.

Mono-decomplexation could be achieved by treating solutions of 5 with a 5-fold excess of acetonitrile. Stirring the solutions for several hours at ambient temperature afforded a mononuclear thioamide complex and acetonitrile pentacarbonyl chromium, $\left[(\mathrm{CO})_{5} \mathrm{Cr}-\right.$ 


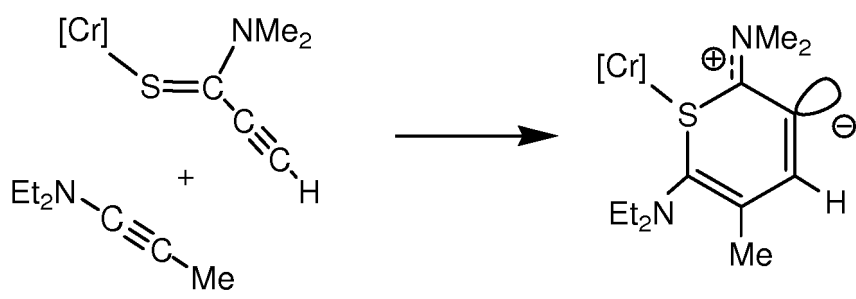

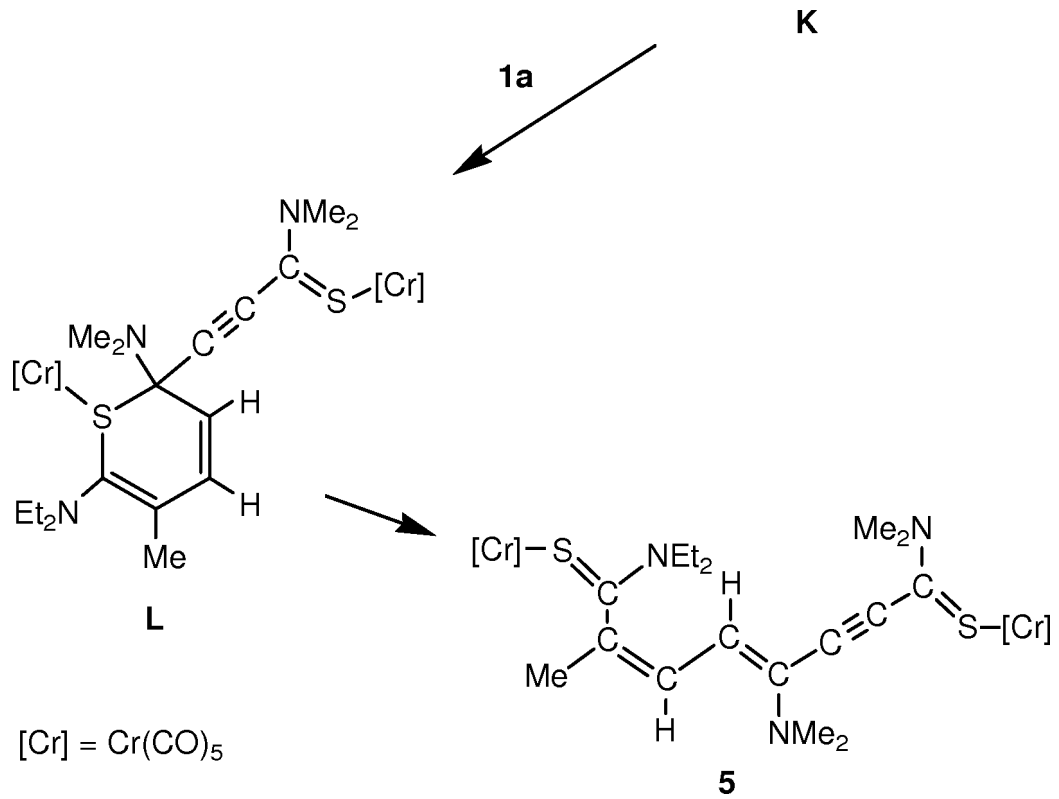

Scheme 7.

$\left.\mathrm{N} \equiv \mathrm{C}-\mathrm{CH}_{3}\right]$. Only one isomer of the thioamide complex was detected and was isolated after chromatographic workup as a red oil in $68 \%$ yield. Based on the shift of the ${ }^{13} \mathrm{C}$ NMR resonances of the $\mathrm{S}=\mathrm{C}-\mathrm{NMe}_{2}$ carbon atoms on decomplexation, the thioamide complex was assigned the structure 6 (Scheme 8). Full decomplexation could not be accomplished, neither by extending the reaction time considerably nor by using acetonitrile in large excess. Substituting pyridine for acetonitrile only led to decomposition of $\mathbf{6}$. The pentacarbonyl chromium moiety could be recovered in the form of the pyridine complex $\left[(\mathrm{CO})_{5} \mathrm{Cr}-\right.$ $\mathrm{NC}_{5} \mathrm{H}_{5}$ ] (92\% yield). The bridging bis(thioamide) ligand was obviously unstable under the reaction conditions employed and gave only unidentified decomposition products. However, when compound $\mathbf{6}$ was treated with $\left[\mathrm{NBu}_{4}\right] \mathrm{Br}$, decomplexation without decomposition could be achieved and the bisthioamide 7 (Scheme 8) could be isolated in $87 \%$ yield.

In summary, complexes derived from propynoic acid thioamide are readily accessible from $\left[(\mathrm{CO})_{5} \mathrm{Cr}-\right.$ $\mathrm{THF}]$ and the free thioamides. The propynoic acid thioamide ligands are moderate Michael acceptors as demonstrated by the addition of diethylamine to the $\mathrm{CC}$ triple bond of $\left[(\mathrm{CO})_{5} \mathrm{Cr}-\mathrm{S}=\mathrm{C}\left(\mathrm{NMe}_{2}\right)_{-}\right.$ $\mathrm{C} \equiv \mathrm{C}-\mathrm{H}]$ and the failure of any reaction with the weaker nucleophile methanol. An unprecedented coupling of two thioamide ligands with one equivalent of diethylaminopropyne is observed in the reaction of 1a with diethylaminoprop-1-yne. The bridging bis(thioamide) ligand in the resulting homodinuclear complex $\left[(\mathrm{CO})_{5} \mathrm{Cr}-\mathrm{S}=\mathrm{C}\left(\mathrm{NEt}_{2}\right)-\mathrm{C}\left(\mathrm{CH}_{3}\right)=\mathrm{C}(\mathrm{H})-\right.$ $\left.\mathrm{C}(\mathrm{H})=\mathrm{C}\left(\mathrm{NMe}_{2}\right)-\mathrm{C} \equiv \mathrm{C}-\mathrm{C}\left(\mathrm{NMe}_{2}\right)=\mathrm{S}-\mathrm{Cr}(\mathrm{CO})_{5}\right]$ can be mono-decomplexed with acetonitrile and liberated completely with $\left[\mathrm{NBu}_{4}\right] \mathrm{Br}$.

\section{Experimental Section}

All operations were performed in an inert gas atmosphere using standard Schlenk techniques. Solvents were dried by distillation from $\mathrm{CaH}_{2}\left(\mathrm{CH}_{2} \mathrm{Cl}_{2}\right), \mathrm{LiAlH}_{4}$ (pentane) or sodium (THF). The silica gel used for chromatography (Baker, silica for flash chromatography) was argon-saturated and otherwise used as supplied. The yields refer to analytically pure substances and are not optimized. Instrumenta- 
<smiles>CCNC(=[SH]C(C)=O)C(C)=CC=C(C#CC(N)=[SH]C(C)(C)C)[N+](=O)[O-]</smiles>

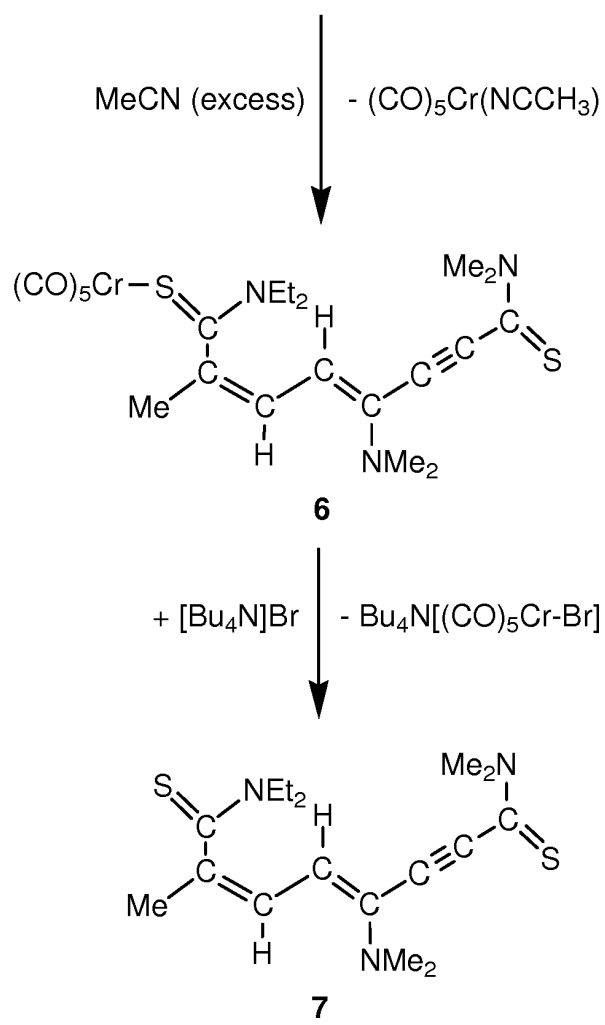

Scheme 8 .

tion: ${ }^{1} \mathrm{H}$ NMR and ${ }^{13} \mathrm{C}$ NMR spectra were recorded with a Jeol JNX 400 and a Varian Inova 400 spectrometer at ambient temperature. Chemical shifts are relative to the residual solvent or tetramethyl silane peaks. IR: Biorad FTS 60. MS: Finnigan MAT 312. Elemental analysis: Heraeus CHN-ORapid. The following compounds were prepared according to literature procedures: $N, N$-dimethyl propyne thioic acid amide [18], N,N-dimethyl-3-trimethylsilyl propyne thioic acid amide [18], N,N-diethylaminoprop-1-yne [19]. All other chemicals were used as purchased from commercial suppliers.

$\left[(\mathrm{CO})_{5} \mathrm{Cr}-\mathrm{S}=\mathrm{C}\left(\mathrm{NMe}_{2}\right)-\mathrm{C} \equiv \mathrm{C}-\mathrm{H}\right](\mathbf{1} \boldsymbol{a})$ and
$\left[(\mathrm{CO})_{5} \mathrm{Cr}-\mathrm{S}=\mathrm{C}\left(\mathrm{NMe}_{2}\right)-\mathrm{C} \equiv \mathrm{C}-\mathrm{Si}\left(\mathrm{CH}_{3}\right)_{3}\right](\mathbf{1 b})$

At r.t. $0.57 \mathrm{~g}(5 \mathrm{mmol})$ of $N, N$-dimethyl propyne thioic acid amide $\{0.93 \mathrm{~g}(5 \mathrm{mmol})$ of $N, N$-dimethyl-3- trimethylsilyl propyne thioic acid amide $\}$ was added to $50 \mathrm{~mL}$ of a solution of $\left[(\mathrm{CO})_{5} \mathrm{Cr}(\mathrm{THF})\right](0.1 \mathrm{M}$ in THF). The reaction mixture was stirred at ambient temperature. The progress of the reaction was monitored by IR spectroscopy. When all of the starting material was consumed (after $c a$. $5 \mathrm{~min}$ ) the solvent was removed in vacuo and the deep red residue was chromatographed on silica gel at $-20{ }^{\circ} \mathrm{C}$ using mixtures of pentane $/ \mathrm{CH}_{2} \mathrm{Cl}_{2}$ (polarity increasing from 3:1 to $1: 1)$ as eluent. The first yellow fraction contained $\left[\mathrm{Cr}(\mathrm{CO})_{6}\right]$. The second intensely red fraction was collected and the solvent removed in vacuo yielding $1.47 \mathrm{~g}(4.80 \mathrm{mmol} ; 96 \%)$ of complex 1a $\{1.75 \mathrm{~g}(4.63 \mathrm{mmol} ; 93 \%)$ of complex $\mathbf{1 b}\}$ as an orange solid.

1a: M. p. $111-113{ }^{\circ} \mathrm{C}$ (dec.). - IR (THF): $v(\mathrm{CO})=2062$ $\mathrm{m}, 1979 \mathrm{w}, 1937 \mathrm{vs}, 1900 \mathrm{~m} \mathrm{~cm}^{-1} ; \mathrm{v}(\mathrm{C} \equiv \mathrm{C})=2100 \mathrm{w}$ $\mathrm{cm}^{-1} .-{ }^{1} \mathrm{H} \mathrm{NMR}\left(400 \mathrm{MHz},\left[\mathrm{D}_{6}\right.\right.$ ] acetone): $\delta=3.01$ (s, 3H, $\left.\mathrm{NCH}_{3}\right), 3.19$ (s, 3H, NCH 3$), 4.80(\mathrm{~s}, 1 \mathrm{H}, \mathrm{CCH}) .-{ }^{13} \mathrm{C} \mathrm{NMR}$ (100 MHz, [D $]$ acetone): $\delta=42.9\left(\mathrm{NCH}_{3}\right), 46.7\left(\mathrm{NCH}_{3}\right)$, $78.9(\mathrm{CCH}), 96.8(\mathrm{CCH}), 178.6(\mathrm{C}=\mathrm{S}), 216.5$ (cis-CO), 223.8 (trans-CO). - MS (FAB): $m / z(\%)=305(43)\left[\mathrm{M}^{+}\right]$, $248(58)\left[(\mathrm{M}-2 \mathrm{CO})^{+}\right], 221(100)\left[(\mathrm{M}-3 \mathrm{CO})^{+}\right], 193(71)$ $\left[(\mathrm{M}-4 \mathrm{CO})^{+}\right], 165(69)\left[(\mathrm{M}-5 \mathrm{CO})^{+}\right] .-\mathrm{C}_{10} \mathrm{H}_{7} \mathrm{CrNO}_{5} \mathrm{~S}$ (305.23): calcd. C 39.35, H 2.31, N 4.59; found C 39.00, H 2.56, N 4.64.

1b: M.p. $89-91{ }^{\circ} \mathrm{C} .-\mathrm{IR}(\mathrm{THF}): v(\mathrm{CO})=2061 \mathrm{~m}$, $1980 \mathrm{w}, 1937 \mathrm{vs}, 1901 \mathrm{~m} \mathrm{~cm}^{-1} ; v(\mathrm{C} \equiv \mathrm{C})$ not found. ${ }^{1} \mathrm{H}$ NMR (400 MHz, [D 6 ]acetone): $\delta=0.08$ (s, 9H, $\left.\mathrm{Si}\left(\mathrm{CH}_{3}\right)_{3}\right), 3.18\left(\mathrm{~s}, 3 \mathrm{H}, \mathrm{NCH}_{3}\right), 3.36\left(\mathrm{~s}, 3 \mathrm{H}, \mathrm{NCH}_{3}\right)$. ${ }^{13} \mathrm{C}$ NMR (100 MHz, [D 6 acetone): $\delta=-0.30\left(\mathrm{Si}\left(\mathrm{CH}_{3}\right)_{3}\right)$, $43.6\left(\mathrm{NCH}_{3}\right), 47.4\left(\mathrm{NCH}_{3}\right), 99.6\left(\mathrm{CCSi}\left(\mathrm{CH}_{3}\right)_{3}\right), 114.6$ $\left(\mathrm{CCSi}\left(\mathrm{CH}_{3}\right)_{3}\right), 179.1(\mathrm{C}=\mathrm{S}), 217.4$ (cis- $\left.\mathrm{CO}\right), 224.6$ (transCO). - MS (FAB): $m / z(\%)=377(23)\left[\mathrm{M}^{+}\right], 321(19)[(\mathrm{M}-$ $2 \mathrm{CO})^{+}$], $293(78)\left[(\mathrm{M}-3 \mathrm{CO})^{+}\right], 265(100)\left[(\mathrm{M}-4 \mathrm{CO})^{+}\right]$, 237 (98) $\left[(\mathrm{M}-5 \mathrm{CO})^{+}\right] .-\mathrm{C}_{13} \mathrm{H}_{15} \mathrm{CrNO}_{5} \mathrm{~S}(377.41)$ : calcd. C 41.37, H 4.01, N 3.71; found C 41.52, H 4.11, N 3.78.

\section{$\mathrm{Li}\left[(\mathrm{CO})_{5} \mathrm{Cr}-\mathrm{S}=\mathrm{C}\left(\mathrm{NMe}_{2}\right)-\mathrm{C} \equiv \mathrm{C}\right](\mathbf{2})$}

At $-78{ }^{\circ} \mathrm{C}$ a solution of $0.67 \mathrm{~mL}(1.0 \mathrm{mmol})$ of methyllithium (1.5 $\mathrm{M}$ in $\mathrm{Et}_{2} \mathrm{O}$ ) was added to a solution of $0.305 \mathrm{~g}$ (1 mmol) of 1a in $20 \mathrm{~mL}$ of THF. The colour of the solution gradually changed from deep-red to orange. The completion of the reaction was indicated by IR-spectroscopy. IR (THF, $\mathrm{cm}^{-1}$ ): $v(\mathrm{CO}): 2035 \mathrm{~m}, 1910 \mathrm{vs}, 1874 \mathrm{~m}$.

\section{$\left[(\mathrm{CO})_{5} \mathrm{Cr}-\mathrm{S}=\mathrm{C}\left(\mathrm{NMe}_{2}\right)-\mathrm{C}(\mathrm{H})=\mathrm{C}(\mathrm{H}) \mathrm{NEt} t_{2}\right](\mathbf{3})$}

At r.t. $0.11 \mathrm{~mL}(1.1 \mathrm{mmol})$ of diethylamine was added to a solution of $0.305 \mathrm{~g}(1 \mathrm{mmol})$ of $\mathbf{1 a}$ in $5 \mathrm{~mL}$ of THF. The colour of the solution instantaneously changed from deepred to orange. After $5 \mathrm{~min}$ at this temperature the solvent was removed in vacuo. The residue was chromatographed on silica gel at $-20{ }^{\circ} \mathrm{C}$ using mixtures of pentane $/ \mathrm{CH}_{2} \mathrm{Cl}_{2}$ 
(polarity increasing from 2:1 to 1:2) as eluent. The orange fraction was collected and the solvent was removed in vacuo to yield $0.37 \mathrm{~g}(0.98 \mathrm{mmol} ; 98 \%)$ of $\mathbf{3}$ as an orange solid.

M. p. $89-91{ }^{\circ} \mathrm{C}($ dec.). - IR THF): $v(\mathrm{CO})=2053 \mathrm{~m}$, $1924 \mathrm{vs}, 1883 \mathrm{~m} \mathrm{~cm}^{-1} .{ }^{1} \mathrm{H} \mathrm{NMR}\left(400 \mathrm{MHz},\left[\mathrm{D}_{6}\right.\right.$ ]acetone): $\delta=0.77\left(\mathrm{t},{ }^{3} J_{\mathrm{HH}}=7.0 \mathrm{~Hz}, 6 \mathrm{H}, 2 \mathrm{NCH}_{2} \mathrm{CH}_{3}\right), 2.97(\mathrm{br}, 10 \mathrm{H}$, $\left.2 \mathrm{NCH}_{3} ; 2 \mathrm{NCH}_{2} \mathrm{CH}_{3}\right), 5.10\left(\mathrm{~d},{ }^{3} J_{\mathrm{HH}}=12.1 \mathrm{~Hz}, 1 \mathrm{H}, \mathrm{HC}=\mathrm{C}\right)$, $7.70\left(\mathrm{~d},{ }^{3} J_{\mathrm{HH}}=12.1 \mathrm{~Hz}, 1 \mathrm{H}, \mathrm{C}=\mathrm{CH}\right) .-{ }^{13} \mathrm{C} \mathrm{NMR}(100 \mathrm{MHz}$, [D $\mathrm{D}_{6}$ ]acetone): $\delta=11.7\left(\mathrm{NCH}_{2} \mathrm{CH}_{3}\right), 14.7\left(\mathrm{NCH}_{2} \mathrm{CH}_{3}\right), 42.9$ (br, 2, $44.1\left(\mathrm{NCH}_{3}\right), 44.1\left(\mathrm{NCH}_{2} \mathrm{CH}_{3}\right), 52.0\left(\mathrm{NCH}_{2} \mathrm{CH}_{3}\right)$, $94.6\left(C=\mathrm{C}-\mathrm{NEt}_{2}\right), 160.1\left(\mathrm{C}=C-\mathrm{NEt}_{2}\right), 192.8(\mathrm{C}=\mathrm{S}), 218.2$ (cis-CO), 225.0 (trans-CO). - MS (EI): $\mathrm{m} / z(\%)=378(10)$ $\left[\mathrm{M}^{+}\right], 322(29)\left[(\mathrm{M}-2 \mathrm{CO})^{+}\right], 294(22)\left[(\mathrm{M}-3 \mathrm{CO})^{+}\right]$, $266(100)\left[(\mathrm{M}-4 \mathrm{CO})^{+}\right], 238$ (37) $\left[(\mathrm{M}-5 \mathrm{CO})^{+}\right] .-$ $\mathrm{C}_{14} \mathrm{H}_{18} \mathrm{CrN}_{2} \mathrm{O}_{5} \mathrm{~S}$ (378.36): calcd. C 44.44, $\mathrm{H} 4.80, \mathrm{~N}$ 7.40; found C 44.58, H 4.61, N 7.14.

\section{$\left[(\mathrm{CO})_{5} \mathrm{Cr}-\mathrm{S}=\mathrm{C}\left(\mathrm{NH}_{2}\right)_{2}\right](4)$}

At r. t. $0.15 \mathrm{~g}(2.0 \mathrm{mmol})$ of thiourea was added to a solution of $0.305 \mathrm{~g}(1 \mathrm{mmol})$ of $1 \mathrm{a}$ in $5 \mathrm{~mL}$ of THF. The progress of the reaction was followed by IR-spectroscopy. When all of the starting material was consumed, the solvent was removed in vacuo and the residue chromatographed on silica gel at $-20{ }^{\circ} \mathrm{C}$ using mixtures of pentane $/ \mathrm{CH}_{2} \mathrm{Cl}_{2}$ (polarity increasing from 1:1 to $0: 1$ ) as eluent. The yellow fraction was collected and the solvent removed in vacuo yielding $0.25 \mathrm{~g}$ $(0.95 \mathrm{mmol} ; 95 \%)$ of $\mathbf{4}$ as a yellow solid. Compound $\mathbf{4}$ was identified by comparison of the spectroscopic data with those published [20].

$\left[(\mathrm{CO})_{5} \mathrm{Cr}-\mathrm{S}=\mathrm{C}\left(\mathrm{NEt}_{2}\right)-\mathrm{C}\left(\mathrm{CH}_{3}\right)=\mathrm{CH}-\mathrm{CH}=\mathrm{C}\left(\mathrm{NMe}_{2}\right)-\mathrm{C} \equiv \mathrm{C}-\right.$ $\left.\mathrm{C}\left(\mathrm{NMe}_{2}\right)=\mathrm{S}-\mathrm{Cr}(\mathrm{CO})_{5}\right](5)$

At r. t. $0.06 \mathrm{~g}(0.5 \mathrm{mmol})$ of $N, N$-diethylaminoprop-1-yne was added to a solution of $0.305 \mathrm{~g}(1 \mathrm{mmol})$ of $1 \mathrm{a}$ in $5 \mathrm{~mL}$ of THF. The reaction mixture was stirred at ambient temperature and the progress of the reaction was monitored by IRspectroscopy. After 30 min the solvent was removed in vacuo and the residue chromatographed on silica gel at $-20{ }^{\circ} \mathrm{C}$ using mixtures of pentane $/ \mathrm{CH}_{2} \mathrm{Cl}_{2}$ (polarity increasing from 1:1 to 1:3) as eluent. The red fraction was collected. The solvent was removed in vacuo yielding $0.31 \mathrm{~g}(0.85 \mathrm{mmol}$; $85 \%)$ of 5 as a red solid.

M.p. $68-70{ }^{\circ} \mathrm{C}$ (dec.). - IR (THF): $v(\mathrm{CO})=2060 \mathrm{~m}$, 1977 vw, 1938 vs, 1929 s, $1897 \mathrm{~m} \mathrm{~cm}^{-1} .-{ }^{1} \mathrm{H}$ NMR $\left(400 \mathrm{MHz}, \mathrm{CDCl}_{3}\right): \delta=1.16\left(\mathrm{t},{ }^{3} J_{\mathrm{HH}}=7.1 \mathrm{~Hz}, 3 \mathrm{H}\right.$, $\left.\mathrm{NCH}_{2} \mathrm{CH}_{3}\right), 1.29\left(\mathrm{t},{ }^{3} J_{\mathrm{HH}}=7.1 \mathrm{~Hz}, 3 \mathrm{H}, \mathrm{NCH}_{2} \mathrm{CH}_{3}\right)$, $1.93\left(\mathrm{~s}, 3 \mathrm{H}, \mathrm{C}=\mathrm{CCH}_{3}\right), 2.77\left(\mathrm{~s}, 6 \mathrm{H}, \mathrm{N}\left(\mathrm{CH}_{3}\right)_{2}\right), 3.46-, 3.53$ (br, $\left.8 \mathrm{H}, \mathrm{N}\left(\mathrm{CH}_{3}\right)_{2} ; \mathrm{NCH}_{2} \mathrm{CH}_{3}\right), 3.88\left(\mathrm{~m}, 1 \mathrm{H}, \mathrm{NCH}_{2} \mathrm{CH}_{3}\right)$, $4.00\left(\mathrm{~m}, 1 \mathrm{H}, \mathrm{NCH}_{2} \mathrm{CH}_{3}\right), 5.10\left(\mathrm{~d},{ }^{3} J_{\mathrm{HH}}=11.8 \mathrm{~Hz}, 1 \mathrm{H}\right.$, $\left.\mathrm{CH}_{3} \mathrm{C}=\mathrm{C}(\mathrm{H})-(H) \mathrm{C}=\mathrm{C}\right), 7.70\left(\mathrm{~d},{ }^{3} J_{\mathrm{HH}}=11.8 \mathrm{~Hz}, 1 \mathrm{H}\right.$, $\left.\mathrm{CH}_{3} \mathrm{C}=\mathrm{C}(H)-(\mathrm{H}) \mathrm{C}=\mathrm{C}\right) . \quad-{ }^{13} \mathrm{C}$ NMR $\left(100 \mathrm{MHz}, \mathrm{CDCl}_{3}\right)$ :
$\delta=10.9,13.7\left(\mathrm{NCH}_{2} \mathrm{CH}_{3}\right), 22.2\left(\mathrm{C}=\mathrm{CCH}_{3}\right), 40.2\left(2 \mathrm{NCH}_{3}\right)$, $42.7\left(\mathrm{NCH}_{3}\right), 46.0\left(\mathrm{NCH}_{3}\right), 46.1,49.4\left(\mathrm{NCH}_{2} \mathrm{CH}_{3}\right), 90.1$ $\left(\mathrm{C} \equiv C-\mathrm{CSNMe}_{2}\right), 97.0\left(\mathrm{C} \equiv \mathrm{C}-\mathrm{CSNMe}_{2}\right), 106.1\left(\mathrm{CH}_{3} \mathrm{C}=\mathrm{C}-\right.$ $\mathrm{C}=\mathrm{C}), \quad 128.0 \quad\left(\mathrm{CH}_{3} \mathrm{C}=\mathrm{C}-\mathrm{C}=\mathrm{C}\right), \quad 128.5 \quad\left(\mathrm{CH}_{3} \mathrm{C}=\mathrm{C}-\mathrm{C}=\mathrm{C}\right)$, $131.8\left(\mathrm{CH}_{3} \mathrm{C}=\mathrm{C}-\mathrm{C}=C\right), 178.7\left(\mathrm{NMe}_{2}-\mathrm{C}=\mathrm{S}\right), 200.9\left(\mathrm{NEt}_{2}-\right.$ $\mathrm{C}=\mathrm{S}$ ), 215.4, 216.3 (cis-CO), 223.2, 223.6 (trans-CO). - MS (EI): $m / z(\%)=721(8)\left[\mathrm{M}^{+}\right], 665(21)\left[(\mathrm{M}-2 \mathrm{CO})^{+}\right], 609$ (22) $\left[(\mathrm{M}-4 \mathrm{CO})^{+}\right], 581(30)\left[(\mathrm{M}-5 \mathrm{CO})^{+}\right], 497(25)[(\mathrm{M}-$ $\left.8 \mathrm{CO})^{+}\right], 473(92)\left[(\mathrm{M}-9 \mathrm{CO})^{+}\right], 441(73)\left[(\mathrm{M}-10 \mathrm{CO})^{+}\right]$, 497 (25) $\left[(\mathrm{M}-10 \mathrm{CO}-\mathrm{Cr})^{+}\right] .-\mathrm{C}_{27} \mathrm{H}_{27} \mathrm{Cr}_{2} \mathrm{~N}_{3} \mathrm{O}_{10} \mathrm{~S}_{2}$ (721.64): calcd. C 44.94, H 3.77, N 5.82; found C 44.96, H 3.78, N 5.82.

\section{$\left[(\mathrm{CO})_{5} \mathrm{Cr}-\mathrm{S}=\mathrm{C}\left(\mathrm{NEt}_{2}\right)-\mathrm{C}\left(\mathrm{CH}_{3}\right)=\mathrm{C}(\mathrm{H})-\mathrm{C}(\mathrm{H})=\mathrm{C}\left(\mathrm{NMe}_{2}\right)-\right.$ $\left.\mathrm{C} \equiv \mathrm{C}-\mathrm{C}(=\mathrm{S}) \mathrm{NMe}_{2}\right](\mathbf{6})$}

At r.t. $2 \mathrm{~mL}$ of acetonitrile was added to a solution of $0.34 \mathrm{~g}(0.47 \mathrm{mmol})$ of $\mathbf{5}$ in $2 \mathrm{~mL}$ of $\mathrm{CH}_{2} \mathrm{Cl}_{2}$. The reaction mixture was stirred at ambient temperature and the progress of the reaction was monitored by TLC. After $c a .6 \mathrm{~h}$ the solvent was removed in vacuo and the residue chromatographed on silica at $-20{ }^{\circ} \mathrm{C}$ using mixtures of pentane $/ \mathrm{CH}_{2} \mathrm{Cl}_{2}$ (polarity increasing from 1:2 to $1: 4$ ) as the eluent. The red fraction was collected and the solvent was removed in vacuo yielding $0.17 \mathrm{~g}(0.32 \mathrm{mmol} ; 68 \%)$ of 6 as a red oil.

IR (THF): $v(\mathrm{CO})=2059 \mathrm{~m}, 1971 \mathrm{vw}, 1935 \mathrm{vs}, 1931 \mathrm{~s}$, $1895 \mathrm{~m} \mathrm{~cm}^{-1}$. $\left.-{ }^{1} \mathrm{H} \mathrm{NMR} \mathrm{(400} \mathrm{MHz}, \mathrm{CDCl}_{3}\right): \delta=$ $1.15\left(\mathrm{t},{ }^{3} J_{\mathrm{HH}}=7.1 \mathrm{~Hz}, 3 \mathrm{H}, \mathrm{NCH}_{2} \mathrm{CH}_{3}\right), 1.25\left(\mathrm{t},{ }^{3} J_{\mathrm{HH}}=\right.$ $\left.7.1 \mathrm{~Hz}, 3 \mathrm{H}, \mathrm{NCH}_{2} \mathrm{CH}_{3}\right), 1.91\left(\mathrm{~s}, 3 \mathrm{H}, \mathrm{C}=\mathrm{CCH}_{3}\right), 2.73(\mathrm{~s}$, $\left.6 \mathrm{H}, \mathrm{N}\left(\mathrm{CH}_{3}\right)_{2}\right), 3.36,3.52\left(\mathrm{~s}, 2 \times 3 \mathrm{H}, \mathrm{NCH}_{3}\right), 3.66(\mathrm{~m}, 2 \mathrm{H}$, $\left.\mathrm{NCH}_{2} \mathrm{CH}_{3}\right), 3.94,4.01\left(\mathrm{~m}, 2 \times 1 \mathrm{H}, \mathrm{NCH}_{2} \mathrm{CH}_{3}\right), 5.11(\mathrm{~d}$, $\left.{ }^{3} J_{\mathrm{HH}}=11.7 \mathrm{~Hz}, 1 \mathrm{H}, \mathrm{CH}_{3} \mathrm{C}=\mathrm{C}(\mathrm{H})-(H) \mathrm{C}=\mathrm{C}\right), 6.43\left(\mathrm{~d},{ }^{3} J_{\mathrm{HH}}=\right.$ $\left.11.7 \mathrm{~Hz}, 1 \mathrm{H}, \mathrm{CH}_{3} \mathrm{C}=\mathrm{C}(H)-(\mathrm{H}) \mathrm{C}=\mathrm{C}\right) .-{ }^{13} \mathrm{C} \mathrm{NMR}(100 \mathrm{MHz}$, $\left.\mathrm{CDCl}_{3}\right): \delta=11.2\left(\mathrm{NCH}_{2} \mathrm{CH}_{3}\right), 14.0\left(\mathrm{NCH}_{2} \mathrm{CH}_{3}\right), 22.8$ $\left(\mathrm{C}=\mathrm{CCH}_{3}\right), 40.3\left(\mathrm{NCH}_{3}\right), 40.9\left(\mathrm{NCH}_{3}\right), 44.0 \quad\left(\mathrm{NCH}_{3}\right)$, 47.0, $50.7\left(\mathrm{NCH}_{2} \mathrm{CH}_{3}\right), 91.3\left(\mathrm{C} \equiv C-\mathrm{CSNMe}_{2}\right), 94.1(C \equiv \mathrm{C}-$ $\left.\mathrm{CSNMe}_{2}\right), 107.0\left(\mathrm{CH}_{3} \mathrm{C}=\mathrm{C}-\mathrm{C}=\mathrm{C}\right), 128.0\left(\mathrm{CH}_{3} \mathrm{C}=\mathrm{C}-\mathrm{C}=\mathrm{C}\right)$, $129.9 \quad\left(\mathrm{CH}_{3} \mathrm{C}=\mathrm{C}-\mathrm{C}=\mathrm{C}\right), \quad 134.0 \quad\left(\mathrm{CH}_{3} \mathrm{C}=\mathrm{C}-\mathrm{C}=\mathrm{C}\right), \quad 176.9$ $\left(\mathrm{NMe}_{2}-\mathrm{C}=\mathrm{S}\right), 201.2\left(\mathrm{NEt}_{2}-\mathrm{C}=\mathrm{S}\right), 217.3$ (cis-CO), 224.3 (trans-CO). - MS (EI): $m / z(\%)=529(16)\left[\mathrm{M}^{+}\right], 473(51)$ $\left[(\mathrm{M}-2 \mathrm{CO})^{+}\right], 441(46)\left[\left(\mathrm{M}-\mathrm{C}_{3} \mathrm{H}_{6} \mathrm{NS}\right)^{+}\right], 389$ (100) [(M $-5 \mathrm{CO})^{+}$]. $-\mathrm{C}_{22} \mathrm{H}_{27} \mathrm{CrN}_{3} \mathrm{O}_{10} \mathrm{~S}_{2}$ (529.59): calcd. C 49.90, H 5.14, N 7.93; found C 50.33, H 5.50, N 7.34.

\section{$E t_{2} \mathrm{~N}(\mathrm{~S}=) \mathrm{C}-\mathrm{C}\left(\mathrm{CH}_{3}\right)=\mathrm{C}(\mathrm{H})-\mathrm{C}(\mathrm{H})=\mathrm{C}\left(\mathrm{NMe}_{2}\right)-\mathrm{C} \equiv \mathrm{C}-$ $\mathrm{C}\left(=\mathrm{S}_{\mathrm{NMe}}(\mathrm{7})\right.$}

At r. t. $1.0 \mathrm{~g}(3.1 \mathrm{mmol})$ of $\left[\mathrm{Bu}_{4} \mathrm{~N}\right] \mathrm{Br}$ was added to a solution of $0.25 \mathrm{~g}(0.47 \mathrm{mmol})$ of 6 in $10 \mathrm{~mL}$ of THF. The reaction mixture was stirred and the progress of the reaction monitored by IR-spectroscopy. After $24 \mathrm{~h}$ at room temperature the solvent was removed in vacuo. The residue was dissolved in acetone and filtered over a short $(\mathrm{ca} .3 \mathrm{~cm})$ column of silica at $c a .-100{ }^{\circ} \mathrm{C}$. The orange-red fraction was collected and 
the solvent was removed in vacuo. The residue was washed twice with $5 \mathrm{~mL}$ of pentane and twice with $10 \mathrm{~mL}$ of ether each yielding $0.14 \mathrm{~g}(0.41 \mathrm{mmol} ; 87 \%)$ of 2 as an orange oil.

${ }^{1} \mathrm{H}$ NMR $\left(400 \mathrm{MHz}, \mathrm{CDCl}_{3}\right): \delta=1.15\left(\mathrm{t},{ }^{3} J_{\mathrm{HH}}=\right.$ $\left.7.1 \mathrm{~Hz}, 3 \mathrm{H}, \mathrm{NCH}_{2} \mathrm{CH}_{3}\right), 1.25\left(\mathrm{t},{ }^{3} J_{\mathrm{HH}}=7.1 \mathrm{~Hz}, 3 \mathrm{H}\right.$, $\left.\mathrm{NCH}_{2} \mathrm{CH}_{3}\right), 2.11\left(\mathrm{~s}, 3 \mathrm{H}, \mathrm{C}=\mathrm{CCH}_{3}\right), 2.72\left(\mathrm{~s}, 6 \mathrm{H}, \mathrm{NCH}_{3}\right)$, $3.41\left(\mathrm{~s}, 3 \mathrm{H}, \mathrm{NCH}_{3}\right), 3.46\left(\mathrm{~s}, 3 \mathrm{H}, \mathrm{NCH}_{3}\right), 3.61(\mathrm{~m}, 2 \mathrm{H}$, $\left.\mathrm{NCH}_{2}\right), 3.66\left(\mathrm{~m}, 1 \mathrm{H}, \mathrm{NCH}_{2}\right), 4.24\left(\mathrm{~m}, 1 \mathrm{H}, \mathrm{NCH}_{2}\right)$, $5.24\left(\mathrm{~d},{ }^{3} J_{\mathrm{HH}}=12.1 \mathrm{~Hz}, 1 \mathrm{H}, \mathrm{CH}_{3} \mathrm{C}=\mathrm{C}(\mathrm{H})-(H) \mathrm{C}=\mathrm{C}\right)$, $6.06\left(\mathrm{~d},{ }^{3} J_{\mathrm{HH}}=12.1 \mathrm{~Hz}, 1 \mathrm{H}, \mathrm{CH}_{3} \mathrm{C}=\mathrm{C}(H)-(\mathrm{H}) \mathrm{C}=\mathrm{C}\right)$. ${ }^{13} \mathrm{C} \mathrm{NMR}\left(100 \mathrm{MHz}, \mathrm{CDCl}_{3}\right): \delta=13.6\left(\mathrm{NCH}_{2} \mathrm{CH}_{3}\right)$, $19.6\left(\mathrm{NCH}_{2} \mathrm{CH}_{3}\right), 24.0\left(\mathrm{C}=\mathrm{CCH}_{3}\right), 40.3\left(\mathrm{NCH}_{3}\right), 40.9$ $\left(\mathrm{NCH}_{3}\right), 43.8\left(\mathrm{NCH}_{3}\right), 44.7\left(\mathrm{NCH}_{2}\right), 46.9\left(\mathrm{NCH}_{2}\right), 92.5$ $\left(\mathrm{C} \equiv C-\mathrm{CSNMe}_{2}\right), 92.8\left(C \equiv \mathrm{C}-\mathrm{CSNMe}_{2}\right), 108.3\left(\mathrm{CH}_{3} \mathrm{C}=\mathrm{C}-\right.$ $\mathrm{C}=\mathrm{C}), \quad 122.2 \quad\left(\mathrm{CH}_{3} \mathrm{C}=\mathrm{C}-\mathrm{C}=\mathrm{C}\right), \quad 131.6 \quad\left(\mathrm{CH}_{3} \mathrm{C}=\mathrm{C}-\mathrm{C}=\mathrm{C}\right)$, $133.7\left(\mathrm{CH}_{3} \mathrm{C}=\mathrm{C}-\mathrm{C}=C\right), 176.8\left(\mathrm{NMe}_{2}-C=\mathrm{S}\right), 200.9\left(\mathrm{NEt}_{2}-\right.$ $C=\mathrm{S})$. $-\mathrm{MS}(\mathrm{EI}): \mathrm{m} / \mathrm{z}(\%)=337(41)\left[\mathrm{M}^{+}\right], 322(70)[(\mathrm{M}-$ $\left.\mathrm{CH}_{3}\right)^{+}$], $322(100)\left[\left(\mathrm{M}-2 \mathrm{CH}_{3}\right)^{+}\right] .-\mathrm{C}_{17} \mathrm{H}_{27} \mathrm{~N}_{3} \mathrm{~S}_{2}$ (337.54): calcd. C 60.48, H 8.06, N 12.45; found C 60.81, H 8.41, N 12.01 .

\section{Computational details}

All $a b$ initio calculations were performed using Jaguar [21] (version 5.5.016) running on Linux- 2.4.20-28.7smp on six Athlon MP 2400+ dual-processor workstations (Beowulfcluster) parallelized with MPICH 1.2.4. Initial structures were obtained by MM+ optimization using Hyperchem [22].
Geometries were optimized using the LACVP* basis set (ECP for Cr, N31G6* for all other atoms) and the BP86 density functional. The second derivatives at $298.15 \mathrm{~K}$ were calculated to ensure that true minima were found, by showing no large negative frequencies. All reported energies are Gibbs free energies at $298.15 \mathrm{~K}$.

\section{$X$-Ray structural analyses of $\mathbf{1 a}$ and $\mathbf{5}$}

Single crystals suitable for X-ray structural analyses were obtained by slow diffusion of $n$-hexane at $4{ }^{\circ} \mathrm{C}$ into a solution of $\mathbf{1 a}$ and $\mathbf{5}$ in $\mathrm{CH}_{2} \mathrm{Cl}_{2}$. The measurements were performed with a crystal mounted on a glass fibre on a Siemens $\mathrm{P} 4$ diffractometer (graphite monochromator, $\mathrm{Mo} K_{\alpha}$, radiation, $\lambda=0.71073 \AA$ ). For the data collection the Wyckoff technique was used. A semiempirical absorption correction ( $\omega$ scan with 12 reflections) was performed. The structures were solved by Direct Methods using the SHELXTL-97 program package [23]. The position of the hydrogen atoms were calculated by assuming ideal geometry, and their coordinates were refined together with those of the attached carbon atoms as riding-model. All other atoms were refined anisotropically.

CCDC 617198 (1a) and and CCDC 617199 (5) contain the supplementary crystallographic data for this paper. These data can be obtained free of charge from The Cambridge Crystallographic Data Centre via www.ccdc.cam. ac.uk/data_request/cif.
[1] See e.g. (a) D. P. N. Satchell, R. S. Satchell in Supplement D: The chemistry of sulfur-containing functional groups (Eds. S. Patai and R. Rappoport), Wiley, 1993, 599. (b) E. S. Raper, Coord. Chem. Rev. 1994, 129, 91.

[2] (a) H. G. Raubenheimer, G. J. Kruger, A. Lombard, J. Organomet. Chem. 1982, 240, C11. (b) H. G. Raubenheimer, S. Lotz, G. J. Kruger, A. van Lombard, J. C. Viljoen, J. Organomet. Chem. 1987, 336, 349. (c) I. Omae, Coord. Chem. Rev. 1979, 28, 97. (d) S. G. Murray, F. R. Hartley, Chem. Rev. 1981, 81, 365.

[3] Y. Tamaru, M. Kagotani, Z.-I. Yoshida, J. Org. Chem. 1979, 44, 2816.

[4] H. Alper, D. A. Brandes, Organometallics 1991, 10, 2457.

[5] E. Lindner, W. Nagel, Z. Naturforsch. 1977, 32b, 1116.

[6] For reviews on the coordination modes and properties of heteroaldehydes and heteroketones see (a) R. Stumpf, H. Fischer in Trends in Organometallic Chemistry (J. Nenon, Ed.), 1994, Vol. 1, 465. (b) H. Fischer, R. Stumpf, G. Roth, Adv. Organomet. Chem. 1999, 43, 125.

[7] (a) H. Fischer, S. Zeuner, Z. Naturforsch. 1985, 40b, 954. (b) W. A. Schenk, B. Vedder, C. Eichhorn, Inorg. Chim. Acta 2004, 357, 1885.
[8] W. A. Schenk, T. Stur, E. Dombrowski, J. Organomet. Chem. 1994, 472, 257.

[9] (a) R. G. W. Gingerich, R. J. Angelici, J. Organomet. Chem. 1977, 132, 377. (b) H. Fischer, R. Märkl, Chem. Ber. 1982, 115, 1349.

[10] (a) H. Fischer, U. Gerbing, A. Tiriliomis, G. Müller, B. Huber, J. Riede, J. Hofmann, P. Burger, Chem. Ber. 1988, 121, 2095. (b) H. Fischer, A. Tiriliomis, U. Gerbing, B. Huber, G. Müller, J. Chem. Soc., Chem. Commun. 1987, 559.

[11] For more information see: J. Granifo, J. Costamagna, A. Garrao, M. Pieber, J. Inorg. Nucl. Chem. 1980, 42, 1587.

[12] S. Cronje, G. R. Julius, E. Stander, C. Esterhuysen, H. G. Raubenheimer, Inorg. Chim. Acta 2005, 358, 1581.

[13] U. Schubert in Transition Metal Carbene Complexes (K. H. Dötz, H. Fischer, P. Hofmann, F. R. Kreissl, U. Schubert, K. Weiss, Hrsg.) Verlag Chemie, Weinheim 1983, 73.

[14] (a) Y. Tamaru, T. Harada, Z. Yoshida, J. Am. Chem. Soc. 1980, 102, 2392. (b) S. Scheibye, S.-O. Lawesson, C. Rømming, Acta Chem. Scand., Ser. B 1981, $35,239$. 
[15] (a) H. Fischer, A. Tiriliomis, U. Gerbing, B. Huber, G. Müller, J. Chem. Soc., Chem. Commun. 1987, 559. (b) H. Fischer, U. Gerbing, A. Tiriliomis, J. Organomet. Chem. 1987, 332, 105. (c) H. Fischer, U. Gerbing, A. Tiriliomis, G. Müller, B. Huber, J. Riede, J. Hofmann, P. Burger, Chem. Ber. 1988, 121, 2095. (d) H. Fischer, J. Hofmann, U. Gerbing, A. Tiriliomis, J. Organomet. Chem. 1988, 358, 229. (e) H. Fischer, K. Treier, J. Hofmann, J. Organomet. Chem. 1990, 384, 305.

[16] For some examples see: (a) J. Ficini, Bull. Soc. Chim. Fr. 1973, 3367. (b) W. Steglich, Chem. Ber. 1968, 101, 308. (c) I. Pennanen, Heterocycles 1978, 9, 1047. (d) R. Aumann, H. Heinen, C. Krüger, P. Betz, Chem. Ber. 1990, 123, 605. (e) B. M. Trost, T. A. Runge, J. Am. Chem. Soc. 1981, 103, 7559. (f) R. A. Abramovitch,
I. Shinkai, B. J. Mavunkel, K. M. More, S. O'Connor, Tetrahedron 1996, 52, 3339.

[17] W. A. Schenk, T. Beucke, N. Burzlaff, M. Klüglein, M. Stemmler, Chem. Eur. J. 2006, 12, 4821.

[18] K. Hartke, H.-D. Gerber, U. Roesrath, Liebigs Ann. Chem. 1991, 903.

[19] L. Brandsma, in Preparative Acetylenic Chemistry, Elsevier, Amsterdam, Netherlands, 1988, 235.

[20] J. Granifo, J. Costamagna, A. Garrao, M. Pieber, J. Inorg. Nucl. Chem. 1980, 42, 1587.

[21] Jaguar 5.5, Schrödinger, LLC, Portland, Oregon, 2003.

[22] Hyperchem (version 5); Hypercube Inc.: Gainsville FL 32601. [23]

[23] G. M. Sheldrick, SHELX-97: Programs for Crystal Structure Analysis, University of Göttingen, Göttingen (Germany) 1997. 